\title{
The clinical enigma of a Midfacial Destructive lesion
}

\section{Case Report}

\author{
Bhat V.S. ${ }^{1}$, Ravishankar S. N. ${ }^{2}$, Nitha ${ }^{3}$, Rao S. ${ }^{4}$, Naik K.M. ${ }^{5}$ \\ ${ }^{1}$ Dr. Vinay S Bhat, Assistant Professor, ${ }^{2}$ Dr. Ravishankar S N, Resident, ${ }^{3}$ Dr. Nitha, Senior Resident, ${ }^{4}$ Dr. Soorya Rao, \\ Resident, ${ }^{5}$ Dr. Kiran M Naik, Professor; all authors are attached with Department of ENT, Adichunchanagiri Institute Of \\ Medical Sciences, B.G Nagara, Karnataka, India.
}

Address for Correspondence: Dr. Vinay S Bhat, Assistant Professor, Department of ENT, Adichunchanagiri Institute of Medical Sciences, B.G Nagara, Karnataka, India

\begin{abstract}
Midfacial destruction is a rare presentation of various neoplastic, autoimmune and infective disorders. Here we present a rare case of a midfacial distructive lesion in a young patient with xeroderma pigmentosum, which was diagnosed as acantholytic squamous cell carcinoma on histopathological examination.
\end{abstract}

Keywords: Xeroderma pigmentosum, Acantholytic squamous cell carcinoma, Midafacial distructive lesion

\section{Introduction}

Acantholytic squamous cell carcinoma (ASCC) first described by Lever in 1947 is a rare variant of squamous cell carcinoma (SCC) characterized by features of acantholysis of cell nests resulting in a pseudoglandular appearance [1,2] (synonyms: adenoid SCC, angiosarcoma -like SCC, pseudovascular adenoid SCC, pseudoangiosarcomatouscarcinoma, adenoacanthoma) [3].
It accounts for $3-4 \%$ of all squamous cell carcinoma types and most commonly seen in the sun exposed areas of skin particularly of elderly with a male preponderance $[1,2]$.

Here we report a case of young female with Xeroderma Pigmentosum presenting as a destructive lesion of the midface which on further evaluation was found to be Acantholytic squamous cell carcinoma

\section{Case Report}

A 26 year old female presented to the ENT out patient department with 8 days history of bleeding from the nose. She also had complains of continuous dull aching pain from a slow growing ulcer present on the right side of her face. It was associated with foul smelling discharge. The ulcer has been present since one year which started as a small swelling, later ulcerated and progressed to the present size (Fig.1).

Clinical examination revealed an ulcerative lesion about $5 \times 6 \mathrm{cms}$, irregular in shape with everted edges. Floor of the ulcer showed pale granulation tissue with maggots and blood clots. Foul smelling serosanguinous discharge was present. Surrounding skin showed hyperpigmented exfoliative lesions. Patient also had skin lesions all over her body which was present since her childhood. On diagnostic nasal endoscopy a friable mass was seen filling the right nasal cavity extending to left side with septal involvement. It was sensitive to touch and bled on touch.

Examination of the oral cavity revealed a $2 \times 3 \mathrm{cms}$ swelling present over the hard palate, tender, firm and with well defined margins. Multiple biopsy were taken from edges of ulcer, nasal component of the mass and palatal lesion and were sent for histopathological examination.

There were no palpable neck nodes Patient was examined by a dermatologist and was diagnosed to have xeroderma pigmentosum. Family history of similar skin lesions were present in her cousins. Biopsy from the suspicious lesions from patients forehead and back were also taken.

Manuscript received: $20^{\text {th }}$ November 2016

Reviewed: $4^{\text {th }}$ December 2016

Author Corrected; $15^{\text {th }}$ December 2016

Accepted for Publication: $30^{\text {th }}$ December 2016 


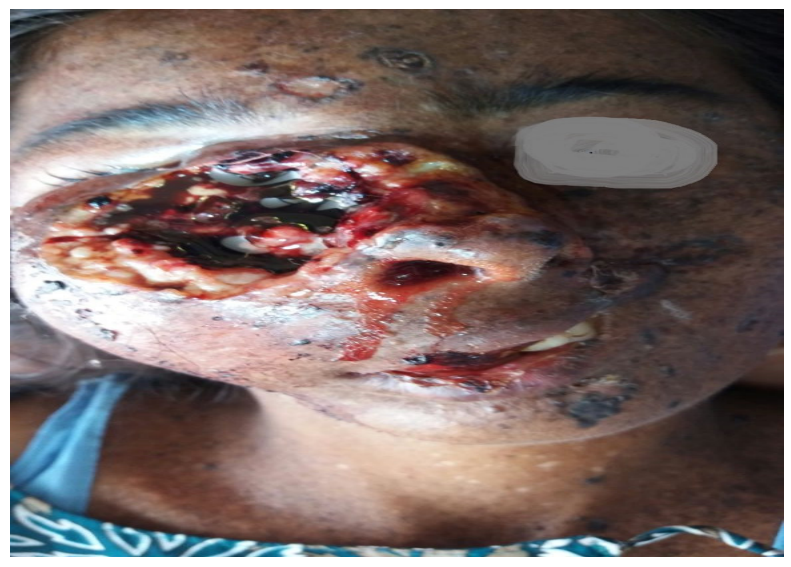

Figure-1: Irregular midfacial destructive ulcer with maggots and blood clots on the right side of face

All routine hematological and biochemical investigations were normal including HIV, HBsAg and VDRL. Chest film and USG abdomen were normal. A contrast enhanced computed tomogram(CECT) showed an ill defined soft tissue density lesion involving the right maxillary sinus extending into the nasal cavity causing destruction of walls of maxillary sinuses, perforation of hard palate with extension into the oral cavity and also extending to the right orbit (Fig. 2).

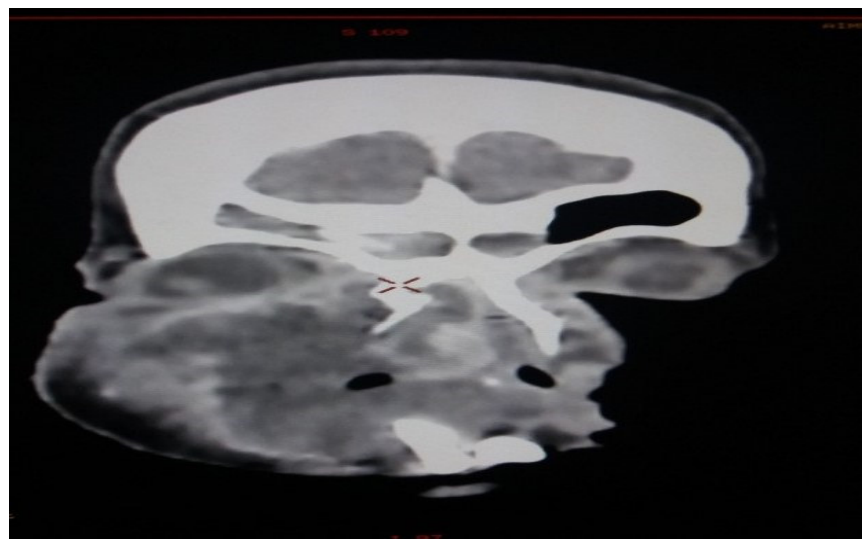

Figure-2: Contrast CT picture showing soft tissue mass involving the maxillary sinuses with destruction of hard palate and extension into the oral cavity

Patient was then started on intravenous broad spectrum antibiotics as well as non steroidal anti inflammatory drugs. Regular debridement of infected ulcer of the midface with removal of maggots was done. On day 4 wound was free of maggots and granulating floor was seen (Fig.3). Patient had marked improvement of pain and facial swelling. There were no further episodes of bleeding from nose.

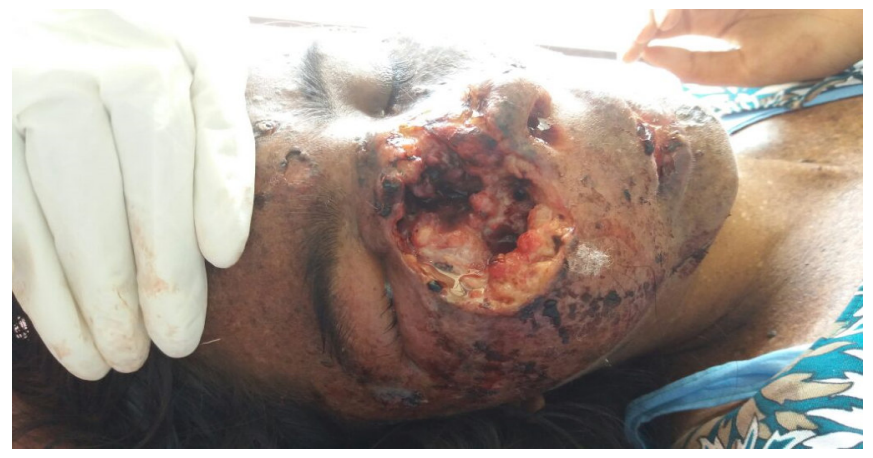

Figure-3: Ulcer after two days of desloughing and cleaning 


\section{Case Report}

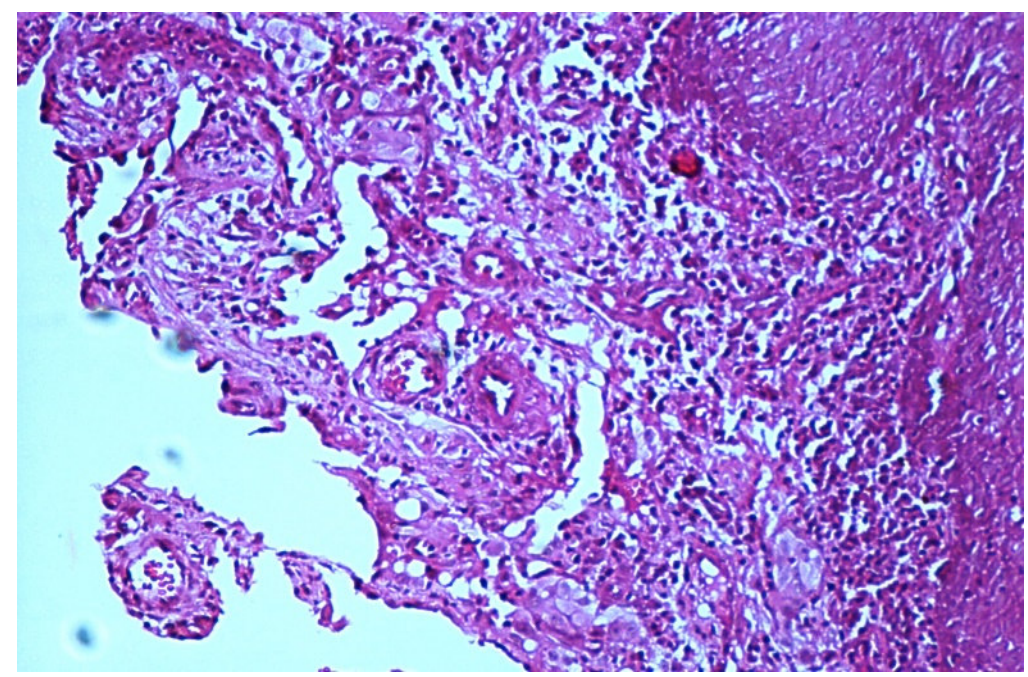

Figure-4: Histopathologic picture showing characteristic pseudoglandular pattern

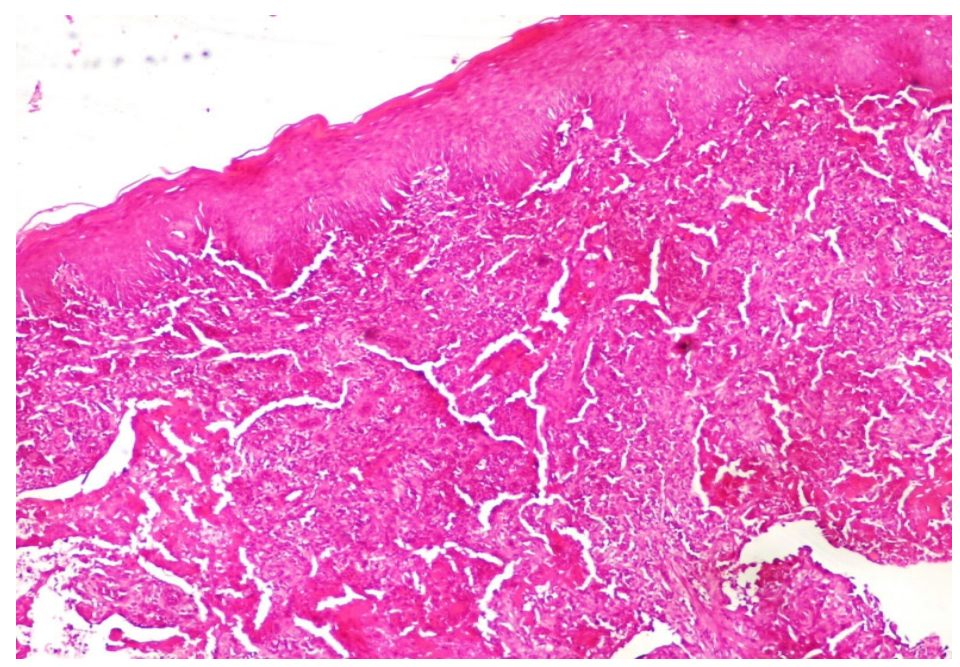

Figure-5: Histopathological picture showing characteristic slit like intratumorous spaces or papillary and pseudopapillary projections

Histopathological examination of biopsy from ulcer edges, nasal mass and palatal swelling revealed final hisopathological diagnosis of rare variant of squamous cell carcinoma known as acantholytic squamous cell carcinoma (Fig 4 \& 5). Histopathological examination of second biopsy specimen taken from other skin lesions over forehead and back showed features of basal cell carcinoma. Patient was advised radical surgery and reconstruction for her midface lesion. Patient refused for any curative treatment and was referred for palliative treatment.

\section{Discussion}

For any progressive destructive lesion of the midface involving the nose, paranasal sinuses and oral cavity the first provisional diagnosis that comes to our mind is Lethal Midline Granuloma. However in this case the patient had features of Xeroderma Pigmentosum( XP) because all the three characteristic features of XP namely freckles, photosensitivity and photophobia were present .This existing skin condition widens our provisional diagnosis since these skin lesions can predispose to a

Tropical Journal of Ophthalmology and Otolaryngology variety of skin cancers including basal cell carcinoma(BCC), squamous cell carcinoma(SCC) and even Malignant melanoma. Our first differential diagnosis was BCC as it happens to be the most common skin cancer in patients with XP. Other supporting factors were the site of the ulcer as well as the history of progression, which started as a nodule and later got ulcerated and developed to the present condition. Second condition that had to be ruled out was SCC, the next common malignant 


\section{Case Report}

condition of the skin [6]. The everted edge and history also favored a squamous variant. Occasionally we even come across patients whose midfacial lesions cannot be classified in any particular group despite all investigations .Such patients are described as suffering from an entity called "idiopathic midline destructive disease".

Acantholytic squamous cell carcinoma is a tumor which was initially considered to arise from the sweat glands [2] due to its tubular and gland like structures was later found to be a distinct variant or SCC. There are very few cases of ASCC documented so far and no specific risk factors have yet been identified. Some proposed predisposing factors include previous scars, burns, human papilloma virus infections, UV radiation and even immunosuppression. The earlier thought of acantholytic actinic keratosis as a precursor lesion is abandoned now since no exact association was found [5]. Documented cases of ASCC originating in patients with chronic lymphocytic leukemia is also present. It is most often found on the head and neck region of elderly, but other sites of origin also have been reported including the vulva, penis, nasopharynx, and breast [8-13]. Intraoral ASCC should be differentiated from angiosarcoma due to its histopathologic similarity with the later. While epitheliod angiosarcoma shows positivity for endothelial markers, ASCC stains positive for only epithelial membrane antigen (EMA) and cytokeratins [7].

Overall the prognosis of ASCC compared to SCC is higher, the high mortality rate is mainly due to refusal of treatment or a reporting bias. The suggested treatment protocol is wide excision of the lesion with a safe margin with prophylactic neck dissection, followed by adjuvant radiotherapy with chemotherapy wherever needed.

Funding: Nil, Conflict of interest: Nil

Permission from IRB: Yes

\section{References}

1. LeBoit PE, Weedon D, Sarasain A, editors.Pathology and genetics of skin tumours. World Health Organization classification of tumours. Lyon : IARC Press; 2006.

2. Lever WF, Adenoacanthoma of sweat glands, Carcinoma of sweat glands with glandular and epidermal elements: report of four cases. Arch Dermatol 1947;56:15.
3. Barnes L, Reichart P, Sidransky P, editors. Pathology and genetics of head and neck tumors. World Health Organization classification of tumours. Lyon: IARC Press; 2005.

4. Kusafuka K, Ebihara M, Ishiki H, Takizawa Y, Iida Y, Onitsuka $\mathrm{T}$, et al. Primary adenoid squamous cell carcinoma of the oral cavity. PatholInt 2006;56:78-83.

5. Johnson WC, Helwig EB. Adenoid squamous cell carcinoma (adenoacanthoma). A clinicopathologic study of 155 patients.Cancer 1966;19:1639-50.

6. Cassarino DS, Derienzo DP, Barr RJ. Cutaneous squamous cell carcinoma: a comprehensive clinicopathologic classification. Part one. J CutanPathol 2006;33:191-206.

7. Underwood JW, Adcock LL, Okagaki T. Adenosquamous carcinoma of skin appendages (adenoid squamous cell carcinoma,pseudoglandular squamous cell carcinoma, adenocanthoma of sweat gland of Lever) of the vulva: a clinical and ultrastructural study. Cancer 1978;42:1851-1858.

8. Lasser A, Cornog JL, Morris JM. Adenoid squamous cell carcinoma of the vulva. Cancer 1974;33:224-227.

9. Watanabe K, Mukawa A, Miyazaki K, Tsukahara K. Adenoid squamous cell carcinoma of the penis.Report of a surgical case clinically manifested with rapid lung metastasis. ActaPatholJpn 1983;33:1243-1250.

10. Takagi M, Sakota Y, Takayama S, Ishikawa G. Adenoid squamous cell carcinoma of the oral mucosa:report of two autopsy cases. Cancer 1977;40:2250-2225.

11. Zaaatari GS, Santoianni RA. Adenoid squamous cell carcinoma of the nasopharynx and neck region. Arch Pathol Lab Med 1986;110:542-546.

12. Eusebi V, Lamovec J, Cattani MG, Fedeli F, Millis RR. Acantholytic variant of squamous cell carcinoma of the breast. Am J SurgPathol 1986;10:855-861.

13. Zaatari GS, Santoianni RA, Adenoid squamous cell carcinoma of the nasopharynx and neck region. Arch Pathol Lab Med 1986;110:542-6.

\section{How to cite this article?}

Bhat V.S., Ravishankar S. N., Nitha, Rao S., Naik K.M.The clinical enigma of a Midfacial Destructive lesion. Trop J Ophthalmol Otolaryngol.2016;1(1):3-6. doi: 10.17511/jooo.2016.i01.02. 